\title{
Gingival Sulcus
}

National Cancer Institute

\section{Source}

National Cancer Institute. Gingival Sulcus. NCI Thesaurus. Code C114645.

The space between a tooth and the surrounding ging ival tissue and lined by the sulcular epithelium. 